\title{
Securing Library and Information Resources: The Situation in Two State University Libraries in Cameroon
}

\author{
Rosemary M. Shafack
}

\section{ABSTRACT}

Information services such as the library, under normal international standards should consider safety and security of its infrastructure and resources (human resources inclusive) as part of its workflow. Information is expanding and covering untold grounds every day and information bearing facilities are equally being transformed with the help of Information and Communication Technologies (ICTs) whose evolution seem to know no bounds. This trend is not only changing the role of the Library and Information Professional but urging this professional to ensure the security of access to the information resources platform. Thus it is not only worthwhile to collect, organize and make accessible information resources but it is equally important to secure these resources to last long and prevent unauthorized and unethical access. This therefore calls for a carefully developed security policy for every information service that can be updated as knowledge expands and the ICT platform continue to expand and evolve. Such a policy should be well thought out to cover all the forms information takes and include, print, electronic and graphics. It should equally include securing the human resources implicated in the running and using of the Library services. This paper is an investigation of the challenges faced in securing information resources in public university libraries in Anglophone Cameroon. The research design used for the study is a survey with data collecting instruments made of a questionnaire and an interview guide from library staff and library administrators respectively. Three main research questions were coined for the study having as thrust the following: security challenges faced, security policies put in place to secure library resources and difficulties libraries face in providing appropriate security and how these difficulties could be solved. The analysis of the data collected was done by a simple calculation of the percentages of the responses of the respondents to determine the threats and the extent of each threat. Academic libraries have been plagued with security issues for a long time. It is difficult to replace materials that are under security threats in libraries. Theft, mutilation and unauthorised access to libraries and their resources constitute serious problems which affect users. It is important that libraries with physical security systems reinforce these systems with electronic security systems. More effort is needed to properly train and encourage staff to be security conscious and to take the necessary precautionary measures. It is anticipated that if the right measures are put in place to resolve library security issues, libraries would be able to better protect their resources and render better services.

Keywords: Information Resources, Securing Library,

\section{INTRODUCTION}

Information services such as the library, under normal international standards should consider the safety and security of its infrastructure and resources (human resources inclusive) as part of its workflow. Securing information services resources is the practice of preventing information, information bearing materials or facilities and infrastructure from unauthorized access, use, disclosure, disruption, modification, perusal, inspection, recording or destruction (Omosekejimi, Ijiekhuamhen, \& Ojeme, 2015). Information is expanding and covering untold grounds every day and information bearing facilities are equally being transformed with the help of Information and Communication Technologies (ICTs) whose evolution is boundless. This trend is not only changing the role of the Library and Information Professional but urging this professional to ensure the security of access to the information resources platform. Thus it is not only worthwhile to collect, organize and make accessible information resources but it is equally important to secure these resources to last long and prevent unauthorized and unethical access.

This therefore calls for a carefully developed security policy for every information service that can be updated as 
knowledge grounds and the ICT platform continue to expand and evolve. Such a policy should be well thought out to cover all the forms information takes and include, print, electronic and graphics. It should equally include securing the human resources implicated in the running and using of the Library services. This paper focuses on the state of security in University Libraries in Cameroon.

The University Library is an academic Library. The academic Library has been described as the heart of an institution such as the University (Radhakrishnan, 2016).

The academic health, intellectual vitality and effectiveness of such an institution, therefore closely depends on the state of health and excellence of its Library. Following (Kwaanpong, 2009), "An inert and moribund Library invariably means an inert and moribund University"; it is evident that the strategic position of the University Library cannot be overemphasized. This is more so because, although information may be obtained from other information systems and platforms outside of the Library, the processes are usually not easy and the amount quite overwhelming needing sourcing skills that are not usually posed by the information user (Shafack, 2007). The special role of the Library becomes useful here because its major role is to enhance access to information. Access to information is critical because it is a fundamental human right given its value to every human being in formal and informal settings. The Library provides the opportunity and platform where information on different subject backgrounds can be available to a great extent, with expert services to guide users on how to quickly locate and retrieve what they need. Given this strategic position and role of the Library in general and the academic Library in particular, and the heavy and expensive nature of setting up information systems that can effectively meet the requisite needs of institution community members, it is more pressing for the library administration to provide security for their resources.

\section{PROBlem AND MeTHOD}

This paper is an investigation of the challenges faced in securing information resources in public university libraries in Anglophone Cameroon. The research design used for the study is a survey with data collecting instruments made of a questionnaire and an interview guide from library staff and library administrators respectively. These data collecting instruments were structured in line with the following research questions that were formulated to guide the study.

\section{A. Research Questions}

1. What security challenges are faced?

2. What security policies are in place to secure library resources?

3. What difficulties does your library face in providing appropriate security and how can they be solved?

\section{LITERATURE}

\section{A. Concept of Library Security}

The concept of security is broad in scope and coverage. This has given rise to different definitions of security. Some of these definitions amongst many include:

i) Preservation of confidentiality, integrity and availability of information, in addition to other properties, such as authenticity, accountability, non-repudiation and reliability can also be involved. (https://en.wikipedia.org/wiki/Enterprice_information_secur ity_architecture)

ii) The protection of information bearing materials from unauthorized access, use, disclosure, disruption, modification, or destruction in order to provide confidentiality, integrity and availability (Barker, 2003)

iii) The process of protecting intellectual property of an organization (Pipkin, 2000).

iv) Protection of information bearing materials and minimizing the risk of exposing information to unauthorized parties (Venter \& Eloff , 2003).

\section{FEATURES OF A GOOD LIBRARY SECURITY SYSTEM}

Integrity (which is the accuracy and consistency of the data over its entire life-cycle) is a crucial aspect of a good security system. This means that data and information cannot be modified in an unauthorized or undetected manner which is different from referential integrity in databases. Integrity is violated when content is actively modified in transit. Availability is another important feature of an information security system. Thus for any information bearing materials and system to serve their purpose, the materials, systems and information contained in them must be available when needed (Spagnoletti \& Resca, 2008).

A good library security system must be authentic. Information security in libraries is necessary to ensure that information bearing materials be it in electronic or print forms are genuine (Schelienger \& Teiyel, 2003). Information security systems incorporate authentication features such as "digital signatures", which give evidence that the data are genuine.

\section{MAJOR AREAS OF FOCUS FOR LIBRARY SECURITY}

\section{A. Physical Protection of Library Infrastructure}

The major step in securing library assets includes, physical deterrents which relate to architectural considerations using security hardware and personnel.

The issue of library security starts with planning the library infrastructure. The security of site and landscape design is crucial when putting in place a library building. The aspects of the building to consider include: site lighting at vehicular and pedestrian entrances, circulation areas should be continuous and sufficient to support a secured atmosphere and support appropriate surveillance. Appropriate and clear signage should be provided, including off-site and entrance signage as well as on-site signage that should include directional, cautionary, and parking signs for employees, visitors, service vehicles, and pedestrians (Crowe, 2000).

Signs should generally not be used to identify sensitive areas. Landscaping elements should enhance security by deterring unwanted entry while not allowing criminals to conceal themselves from security personnel and electronic surveillance systems. It is crucial to carefully control vehicles that have access to buildings. Various types of buffers and barriers should be evaluated to enhance the landscape design while still providing the appropriate protection to the library infrastructure.

(Lynn, 2001) holds and rightly so that the following areas of the library generally pose threats when discussing security 
issues unless they are appropriately addressed in the design of the library infrastructural facilities. These include:

1. Exterior entrances

2. Archive and special collection storage spaces

3. Special collection reading areas

4. Children's library area

5. Critical building component locations such as electrical switchgear, communication and security equipment and building control centres

6. Public toilets

7. Loading docks, mail rooms, and shipping and receiving areas.

8. Stairwells

9. Office locations

10. Roof access

It is imperative for architects designing tailor made buildings like library buildings to incorporate and address appropriate and standard security requirements.

\section{B. Security Personnel}

Security personnel should constitute part and parcel of the security plan of the library. The library security team should evaluate the value and need for security personnel, during both non-working and working hours as well as after the library is closed. Such security personnel are needed to patrol within the facility as well as on the grounds and operate an available electronic surveillance system. They may also be used to enforce appropriate library access at the entrances into the building (Omosekejimi, Ijiekhuamhen, \& Ojeme, 2015).

\section{Window Protection}

There are many window security gadgets including, locks, guards, grilles, bars, screen, and films. For best control, windows should be secured by key-operated locks (not simple batch). Windows can be protected against burglary and vandalism by using guards, grilles, bars, security screens and films. Although the use of guards or bars is not always architecturally acceptable, they can be very cost effective (Cherdanseva \& Hilton, 2013). There are standard norms for the use of the above security gadgets that should be respected when the decision to use is taken.

\section{Door Protection}

Some door protection options include cylindrical locks, deadbolts, mortise locks and gates. Gates are needed when there is high risk of burglary through accessible doors though not very suitable in case of fire (Crowe, 2000). Folding gates (fold easily back and out of the way when people or equipment need to pass and provide a lockable barrier when closed) are better to make facilities more secure and still allow frequent and easy access. There are also turnstiles that are equally suitable security gadgets and are user friendly.

\section{E. Re-Inforcing Library Physical Security Using Telecommunication}

The evolution of telecommunication provides suitable means and ways of re-inforcing any physical security system of the library. The major element of any electronic or telecommunication security includes, burglary protection, collection security, electronic access control and video surveillance. These can go a very long way to re-enforce any physical security system.

\section{F. Burglary Protection}

There are different electronic systems that can be employed to prevent burglary into the library building. The most familiar one is the sensor. Sensors can be active of passive, convert or visible, volumetric or line detection or they can be defined by their mode of application (Omosekejimi, Ijiekhuamhen, \& Ojeme, 2015). The experts and the library authority can get what is appropriate for their situation.

Door and window contacts can be used to trigger an alarm whenever library doors or windows are opened without authorization and can be attached to recess within the door or window frame to detect movement.

\section{G. Electronic Collection Security}

Many ways have been developed for securing library collection electronically. These ensure that no material leaves the library without being checked out. These systems always contain a security device that is placed on the materials or information resources such as books, magazines, videos and audio tapes, CDs, DVDs, etc. This device works with a detection device that is typically located at the exit of the library. The detection device must be safe from magnetic media and usually have audible or visible alarms which can be a voice alarm for example. There are two major methods currently used for detection and include: Electromagnetic and Radio Frequency Identification (RFID). RFID solutions are being designed to improve library operations and efficiency (Parkus, 2003).

\section{H. Electronic Access Control into Library Buildings}

Electronic access technology is the best system for controlling access to library buildings, facilities, resources and rooms. Authorized persons are allowed to enter a controlled area by automatically unlocking doors with the use of plastic access cards. These cards are inexpensive and software can be programmed to restrict access to certain areas while recording the time and location of authorized and unauthorized access. From Dean's findings (Dean, 2004), extra security access control can be used in conjunction with video surveillance to control and monitor large collections and equipment. Accessibility functions can be integrated into photo ID Cards for Library employees and these can be used as temporary keys for library clientele to give them access to restricted areas. The electronic access system can be used for monitoring employee time and attendance, security patrols of property and can limit access to sensitive areas, information and equipment. Library authority and experts in this area can work together to determine the appropriate electronic access system they need.

There are entry keypads that can be included within access control systems for entry without a card. There are also biometric entry systems that are available with fingerprint recognition, palm recognition and scanning system for high security measure (Omosekejimi, Ijiekhuamhen, \& Ojeme, 2015).

\section{Library Security Using Video Surveillance}

Video surveillance and closed - circuits television (CCTV) systems serve as a way to monitor and record security, deter crime and ensure safety. Advances in CCTV technology and reduction in cost have made video surveillance a cost effective management tool for library facilities. Libraries can use CCTV to identify visitors, employees, work areas, deter theft and ensure that evidence records on clientele and staff misconduct are kept (Mccahill \& Norris, 2002). (Marcus, 
2007) lists the following library areas that can be monitored by surveillance motion detection imaging and camera:

1. Driveway to the Library building

2. Parking area of the Library

3. The Library self and reading areas

4. Library equipment

5. Movement of staff and users

6. Exchange of materials

From literature, it is evident that telecommunication or electronic security systems have greatly helped and can greatly help libraries to provide maximum security for their resources and equipment although not without challenges.

\section{J. Securing Library and Information Resources in the Universities of Bamenda and Buea}

Based on proposed standard concepts of library security, areas to focus on with respect to library security, physical and electronic library security methods, a study of the situation of the security of library and information resources was carried out.

\section{FINDINGS AND DISCUSSIONS}

The study resulted in the following results that have been discussed in line with the research questions.

\begin{tabular}{lcccc}
\multicolumn{5}{c}{ TABLE I: Respondents to Research Instruments } \\
\hline Institution & $\begin{array}{l}\text { Interview } \\
\text { Number of } \\
\text { Questionnaire } \\
\text { Administered }\end{array}$ & $\begin{array}{l}\text { Directors } \\
\text { and } \\
\text { Deputy } \\
\text { Directors }\end{array}$ & $\begin{array}{l}\text { Number of } \\
\text { instrument } \\
\text { returned }\end{array}$ & $\begin{array}{l}\text { Percentage } \\
\text { Return } \\
\text { Rate }\end{array}$ \\
\hline University of Bamenda & 16 & 2 & 14 & 87.5 \\
University of Buea & 32 & 2 & 31 & 96.9 \\
Total & 48 & 4 & 45 & 93.75 \\
\hline
\end{tabular}

Table 1 presents the response rate to instruments used for data collection for this study. It is evident that the response rate was good with an average score of over $80 \%$.

\section{A. Security Challenges Faced by the University of Bamenda and Buea Libraries}

In relation to the research question on security challenges faced by the two university libraries studied, there were three main items that constituted the thrust of the investigation and the results gotten have been presented on figures 1, 2 and 3 . These items included, familiarity with issues of security and threat that libraries are exposed to and insecurity experiences of theses libraries.

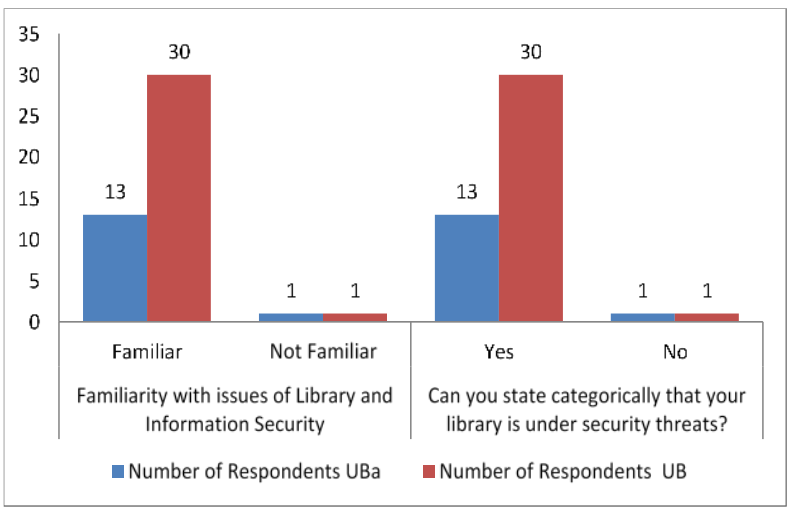

Fig. 1. Familiarity with Issues of Library Security
Relating to how familiar staff of the two academic libraries are with issues of security, figure 1 presents the results of the study. Almost all of the staff of the two libraries were familiar with issues of library security with 13 out of 16 and 30 out of 32 for the universities of Bamenda and Buea respectively. Over $80 \%$ (13) and 90\% (30) of these staff of the universities of Bamenda and Buea were categorical that their libraries face threats of insecurity. The findings are an indication that these two academic libraries need to sit up as far as issues of security are concern. This constitutes a critical part of preservation which is a crucial part of library management. If library resources are not preserved, there will not be sustainability and resources will be endangered and eventually wasted. The impact of this can be enormous. These libraries need to come up with current preservation policies that should incorporate appropriate steps and conservation techniques to prevent library resources from all threats of insecurity.

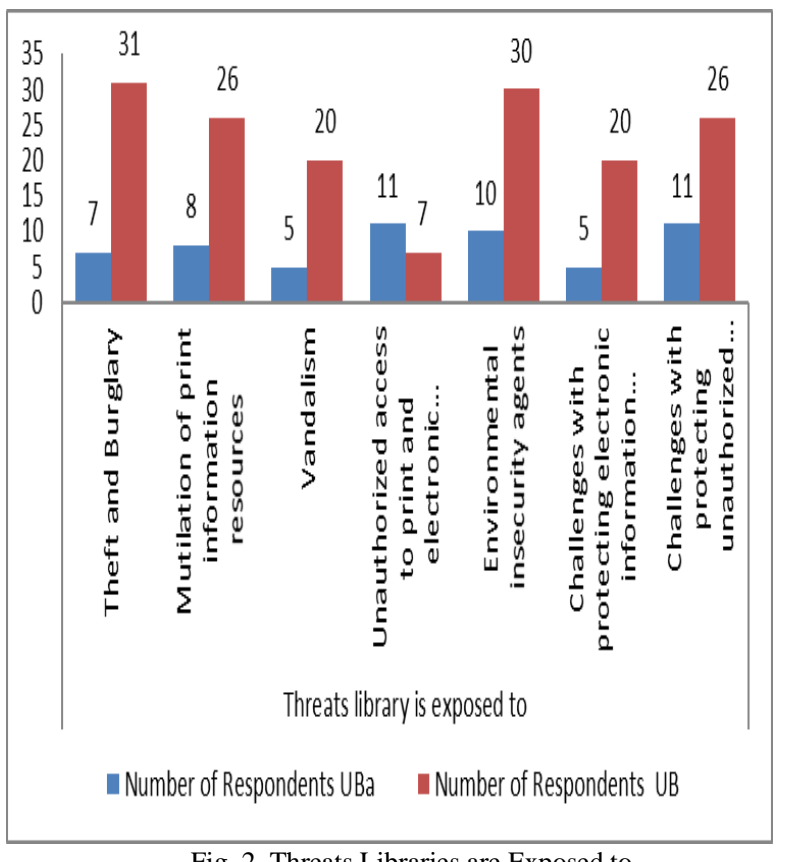

Fig. 2. Threats Libraries are Exposed to

With respect to the types of threats these libraries face, it was evident that both libraries face threats of a similar nature and of different types though at different magnitudes. With respect to nature of the threats faced, we had 7 and 31 respondents for the UBa and UB libraries respectively who said theft and burglary were serious threats to library resources and the magnitude is higher for the UB library. Insecurity as a result of unauthorized access to building, offices and collection areas constitutes another serious cause for concern with 8 and 26 respondents agreeing for UBa and UB respectively; was followed by environmental threats with 10 for UBa and 30 for UB agreeing. The mutilation of resources was confirmed by 8 for UBa and 26 for UB. 


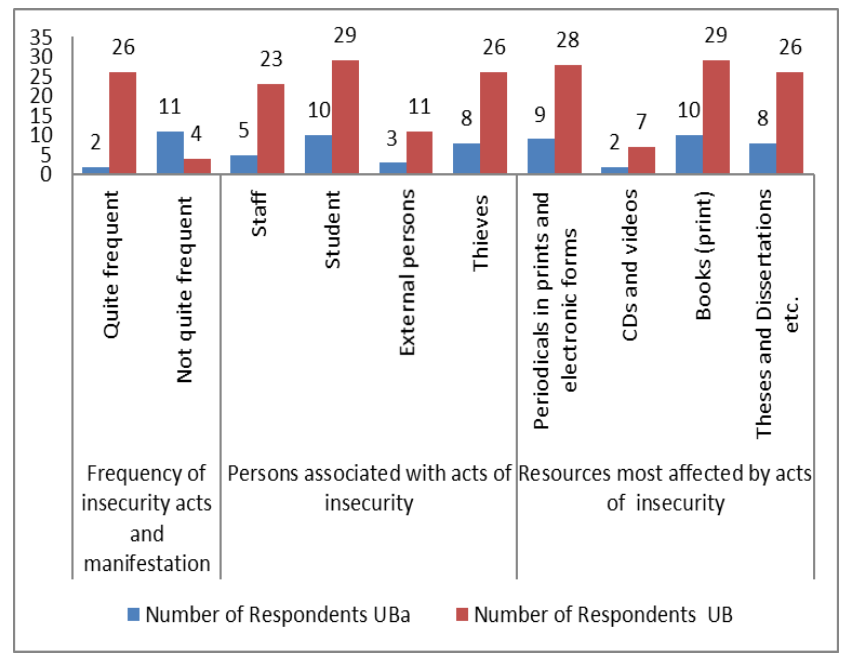

Fig.3. The Insecurity Experiences of Libraries

From the perspective of insecurity experiences, all two libraries had very memorable insecurity experiences with the University of Buea library experiencing frequent acts of insecurity as compared to the University of Bamenda. Concerning persons associated with acts of insecurity, UBa experiences acts of insecurity mostly from students and thieves while UB's experience was greatly with staff, students and thieves with students topping the list. In relation with resources most affected by acts of insecurity, UBa listed print periodicals, books and theses/dissertations. UB on its part listed the same resources.

From the findings, one can conclude that university libraries are under serious security threats and need to pay great attention and take appropriate measures, to protect the libraries and resources. The first step to do this is by developing a good security policy. This is of utmost importance because library security requires budgetary management support, staff, software and need to upgrade hardware for the achievement of their security goals. This is supported by (Omosekejimi, Ijiekhuamhen, \& Ojeme, 2015) and requires appealing to the library management or the university authority as in the case of UBa and UB to release funds that are needed to ensure that the security system works at all times.

\section{B. Security Policy on Library and Information Resources}

\begin{tabular}{|c|c|c|c|}
\hline \multirow[t]{2}{*}{ No. } & \multirow{2}{*}{$\begin{array}{l}\text { Interview } \\
\text { Question }\end{array}$} & \multicolumn{2}{|c|}{ Responses } \\
\hline & & UBa & UB \\
\hline 1. & $\begin{array}{l}\text { Has your library } \\
\text { a security } \\
\text { policy? }\end{array}$ & Yes (100\%) & Yes (100\%) \\
\hline 2. & $\begin{array}{l}\text { Is the policy } \\
\text { developed } \\
\text { separately or } \\
\text { integrated with } \\
\text { the general } \\
\text { library policy? }\end{array}$ & $\begin{array}{l}\text { Issues of library } \\
\text { security are } \\
\text { included in the } \\
\text { general policy }\end{array}$ & $\begin{array}{l}\text { The electronic policy applied } \\
\text { using telecommunications is } \\
\text { separated from the physical } \\
\text { one }\end{array}$ \\
\hline 3. & $\begin{array}{l}\text { What aspects of } \\
\text { the Library are } \\
\text { covered by the } \\
\text { security policy? }\end{array}$ & $\begin{array}{l}\text { collection, } \\
\text { building and } \\
\text { staff in the main } \\
\text { and basically } \\
\text { physical security }\end{array}$ & $\begin{array}{l}\text { The building, collection (both } \\
\text { print and electronic) security } \\
\text { systems are in place, } \\
\text { equipment, users, office areas, } \\
\text { etc. }\end{array}$ \\
\hline 4. & $\begin{array}{l}\text { Is the policy } \\
\text { officially } \\
\text { endorsed by the } \\
\text { University } \\
\text { authority? }\end{array}$ & $\begin{array}{l}\text { Yes, the policy is } \\
\text { officially } \\
\text { endorsed and } \\
\text { integrated in the } \\
\text { rules governing } \\
\text { the library }\end{array}$ & $\begin{array}{l}\text { The policy is officially } \\
\text { approved and takes the form of } \\
\text { security plan, rules and } \\
\text { regulation governing the use of } \\
\text { the library in the student guide }\end{array}$ \\
\hline
\end{tabular}

The staff of the two libraries agreed that they have written policies approved by the University authorities. The University of Bamenda's policy is integrated with the general policy governing the library and its resources while that of the University of Buea is in two parts. In UB, the electronic policy applied with the help of telecommunications is separate from the physical one. Although UBa has not got a policy that is actually applied with the help of telecommunications, the security policies of the two university libraries touch on critical aspects of the library and its resources generally as highlighted on table 3 . The policies generally enforce library rules and regulations, caters for the library collection with respect to unauthorized access, theft, burglary, to name just these.

A written policy is a clear indication of management's support efforts to properly protect the library and its resources. Cronin (1980) and Brown (2007) indicated that the need for a written policy is primordial for it to be effective for the security of library resources. It has been emphasised that, it is not just enough to have a library security policy but to ensure that it is evaluated time and again to upgrade it living up to current trends. It is equally important to seek the views of all library stake holders regarding security issues when evaluating a policy. This will help to cover all the grounds as the library management alone cannot know all the sensitive areas and issues to be incorporated into the policy for it to be effective.

\section{Security Measures Put in Place to Protect Libraries and Resources}

The two state university libraries are very cautious as far as measures to prevent library security are concerned. The measures put in place against security threats can be appreciated from two major perspectives; the physical and electronic measures and presented on figures 4 and 5 . 


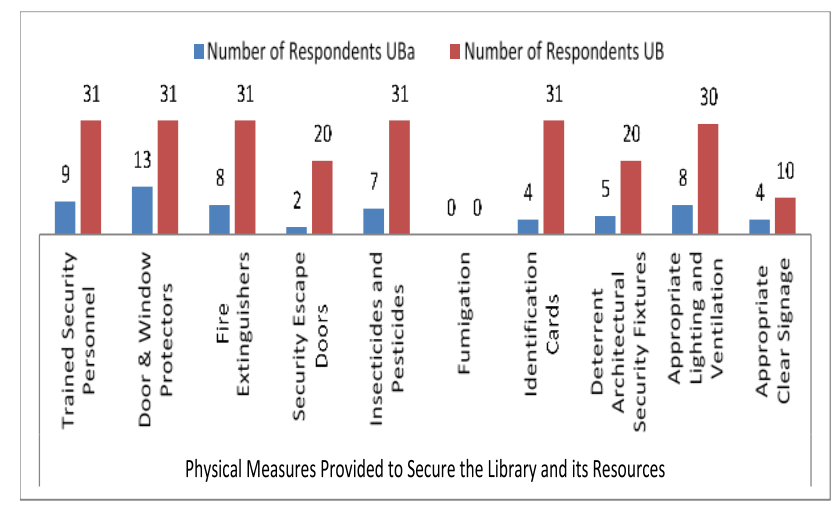

Fig.4. Physical Measures Provided for the Security of library Resources

All two libraries have trained security personnel present at the exit of the libraries who check library the identification documents of users and some patrol within the library in order to create awareness amongst users to prevent them from carrying out any unwanted activity that can be dangerous to the library resources. Their windows have security protectors, grilles and bars that prevent any resource from being thrown out. The doors have locks, deadbolts and mortise locks for security purposes. The challenge with these security mechanisms is that in case of danger, it will be difficult for persons to escape. Both libraries use large quantities of insecticide to deter insects, termites, roaches but these chemicals are not friendly to paper resources. Fire extinguishers are available in a good number which is an indication that both libraries are ready to combat any fire incident. (Shuman , 2002)) and (Alegbeleye, 1993) have each supported the need to put in place the above physical mechanisms to prevent insecurity against the library and its resources including human resources. Although the two libraries have made efforts to secure their libraries and their resources manually, there are quite some very current gadgets that could be acquired to upgrade what they have.

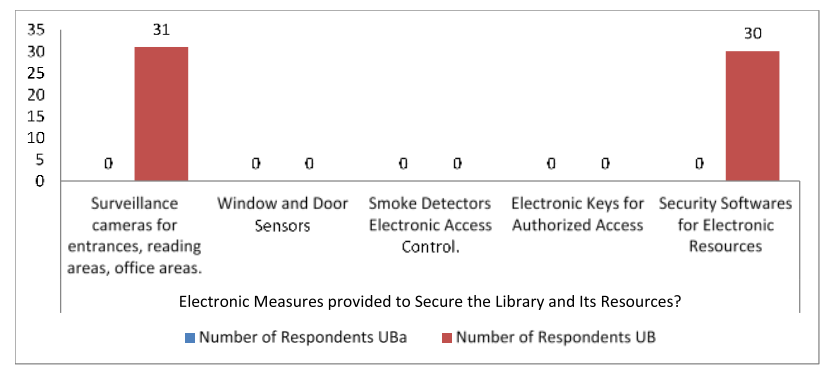

Fig.5. Electronic Measures Provided for the Security of Library Resources

The second form of security investigated is the electronic or telecommunication related system. With respect to these, it was evident that it is only the University of Buea Library that is making great strides to developing an electronic security system to reinforce the physical system of security for its library and resources. This library has evidence of security surveillance with $98 \%$ of its staff confirming, $96.8 \%$ confirmed security softwares and $51.6 \%$ talked of electronic keys for authorized access to resources. Despite the above efforts, this library still has a lot to do to develop a trustworthy electronic security system.

\section{Difficulties in Providing Appropriate and Current Security System}

Sampling the opinion of the staff of the two libraries on the difficulties their libraries encounter in providing appropriate and current security mechanisms, they mentioned amongst others the following:

1. Inadequate funds: Staff indicated that their library budgets are too limited to facilitate the acquisition of the requisite security gadgets. Although the policy is approved but this is not backed by the budgetary provision that can permit the development of a security system worth the name. It must be noted that having appropriate security systems requires huge investments that most libraries, especially in Central Africa cannot afford. This is supported by (Voters, 2007) who decries the fact that libraries and information centres lack the financial resources to purchase and install the telecommunication security systems and devices that can help to provide the level of security required as a result of budgetary allocations from their parent organizations.

2. Inadequate power supply: There is the issue of either power cuts or shortage which is quite the characteristic of the country. Thus the most suitable security gadgets that need to be driven by energy cannot function even if they are installed.

3. Inadequate staff: There is the lack of literate and skilled personnel that can operate most of the security gadgets (Voters, 2007)

The way forward out of the above include the enlightening and advocacy of the parent authorities of these libraries on the importance of developing good security systems. If this is successfully done, then the library budget will be improved. There is great need to recruit skilled (or train) staff and put in place a user education programme on issues of security and security systems.

\section{CONCLUSION}

Academic libraries have been plagued with security issues for a long time. It is difficult to replace materials that are under security threats in libraries. Theft, mutilation and unauthorised access to libraries and their resources constitute a serious problem which affects users. It is important that libraries with physical security systems reinforce these systems with electronic security systems. More effort is needed to properly train and encourage staff to be security conscious and to take the necessary precautionary measures. It is anticipated that if the right measures are put in place to resolve library security issues, libraries would be able to better protect their resources and render better services.

\section{REFERENCES}

Alegbeleye, B. (1993). Disaster Control Planning for Libraries, Archives and Electronic Data Processing Centres in Africa. Ibadan: Option Books and Information Services.

Barker, W. C. (2003). Guidelines for Identifying an Information System as a National Security System. Retrieved October 2020, from nvlpubs.nist.gov/nistpubs/legacy/sp/nistspecialpublication800_59

Brown, K. E. (2007). Collection Security: Planning and Preservation for Libraries and Archives. Retrieved October 2019, from Technical Leaflet Emergency Management. Section 3 Leaflet 12: http://www.nedee.org 
Cherdanseva, Y., \& Hilton, J. (2013). A Reference model of information assurance and security. workshop in conjunction with the 8th International conference on availability, reliability and security (ARS) University of Regensburg, Germany: IEEE Proceedings.

Cronin, M. J. (1980). A Workshop Approach to Library Security. Library and Archival Security, 3, 30-38.

Crowe, T. D. (2000). Crime prevention through environmental design: Applications of architectural design and space management concepts ( 2 ed.). Butterworth: Stoneham, MA and National Crime Prevention Institute.

Dean, W. (2004). Library and Information Resources Security. Retrieved July 2020, from www.idpublications.org

Kwaanpong, A. (2009, October). Disaster Control measures in academic libraries in Nasarawa State. Retrieved 2019, from www.unn.edu

Lynn, M. (2001). The Design and evaluation of physical protection system. Butterworth: Stonharm, NA guidelines for the security of rare books, manuscripts.

Marcus, N. (2007). Library and Information Resources Security. Retrieved July 2020, from www.idpublications.org

Mccahill, M. N., \& Norris, P. (2002). Electronic Security: A Case Study of IIT, Bombay Central Library, Proceedings of the CALIBER 3. Retrieved November 2019, from www.library.iitb.ac.in/-mnj/

Omosekejimi, A. E., Ijiekhuamhen, O. P., \& Ojeme, T. N. (2015, September 17). Library \& Information resources' security: Traditional and electronic security measures. International Journal of Academic Research and Reflection, 3(3).
Parkus, B. L. (2003). Collection security: Planning and prevention of libraries and archives. Retrieved October 2019, from Parkus, B. L. (2003). Collection security:http://www.nedec.org/plam.3/heat312htm

Pipkin, D. (2000). Information security: Protecting the global enterprise New York: Hewlett Packard Company.

Radhakrishnan, S. (2016). Retrieved September 17, 2019, from htths://hpssmartlibrary.wordpress.com

Schelienger, T., \& Teiyel, S. (2003). Information Security culture - from analysis to change. South African Computer Journal, 31, 46 - 52.

Shafack, R. M. (2007). Managing problems of University Libraries in Cameroon. Unpublished.

Shuman , B. A. (2002). Personal Safety in Library: Levels, Problems and Solutions. The Reference Librarian, 36(75 and 76).

Spagnoletti, P., \& Resca, A. (2008). The duality of information security management: Fighting against predictable and unpredictable threats. Journal of Information Security, 4(3), 46 - 62.

Venter, H. S., \& Eloff , J. H. (2003). A Taxonomy for information security technologies computers and security, 22(4), 299-307. 22(4), 299-307.

Voters, B. (2007). Best Answers Chosen by Voters: Prospect and Problems of the Use of Telecommunication Facilities: The Way Forward Retrieved July 2020, from https://digitalcommons.uni.edu 